\title{
Inactivation of two strains of Escherichia coli inoculated into whole and skim milk by ultrahigh-pressure homogenisation
}

\author{
Wilfido José BRIÑEZ, Artur X. ROIG-SAGUÉS*, \\ M. Manuela HERNÁNDEZ-HERRERO, Buenaventura GUAMIS-LÓPEZ
}

Centre Especial de Recerca-Planta de Tecnologia dels Aliments (CERPTA), XiT, Departament de Cìncia Animal i dels Aliments, Facultat de Veterinària, edifici V, Universitat Autònoma de Barcelona, 08193, Bellaterra (Barcelona), Spain

Received 26 September 2005 - Accepted 16 February 2006

\begin{abstract}
The inactivation by ultrahigh-pressure homogenisation (UHPH) of Escherichia coli ATCC 10536 and Escherichia coli O157:H7 CCUG 44857 inoculated into whole and skim milk was investigated. Samples of UHT whole and skim milk inoculated at a concentration of approximately $7.0 \log _{10}\left(\mathrm{cfu} \cdot \mathrm{mL}^{-1}\right)$ were pressurised in a two-valve system UHPH machine at $300 \mathrm{MPa}$ at the primary homogenising valve and at $30 \mathrm{MPa}$ at the secondary valve. Inlet temperatures of milk were $6{ }^{\circ} \mathrm{C}$ and $20^{\circ} \mathrm{C}$. Viable and injured bacterial counts were measured $2 \mathrm{~h}$ after UHPH treatment and after 3,6 and 9 days of storage at $4{ }^{\circ} \mathrm{C}$. The type of milk significantly influenced $(P<0.05)$ the degree of inactivation reached in both strains of E. coli, being higher at $20^{\circ} \mathrm{C}$ in whole milk. The level of inactivation was similar for E. coli ATCC 10536 and E. coli O157:H7 CCUG 44857, reaching lethality values of 4.30 and $3.94 \log _{10} \mathrm{cfu} \cdot \mathrm{mL}^{-1}$, respectively, at an inlet temperature of $20^{\circ} \mathrm{C}$. No sublethal injuries were detected after treatments. The changes in cultivable cells during storage at $4{ }^{\circ} \mathrm{C}$ were similar in whole and skim milk although the E. coli O157:H7 CCUG 44857 strain showed significant differences, with a decreasing tendency of approximately 0.3 logarithmic units between 0 and 9 days of storage.
\end{abstract}

ultrahigh-pressure homogenisation / lethality / milk / Escherichia coli 0157:H7 / sublethal injury

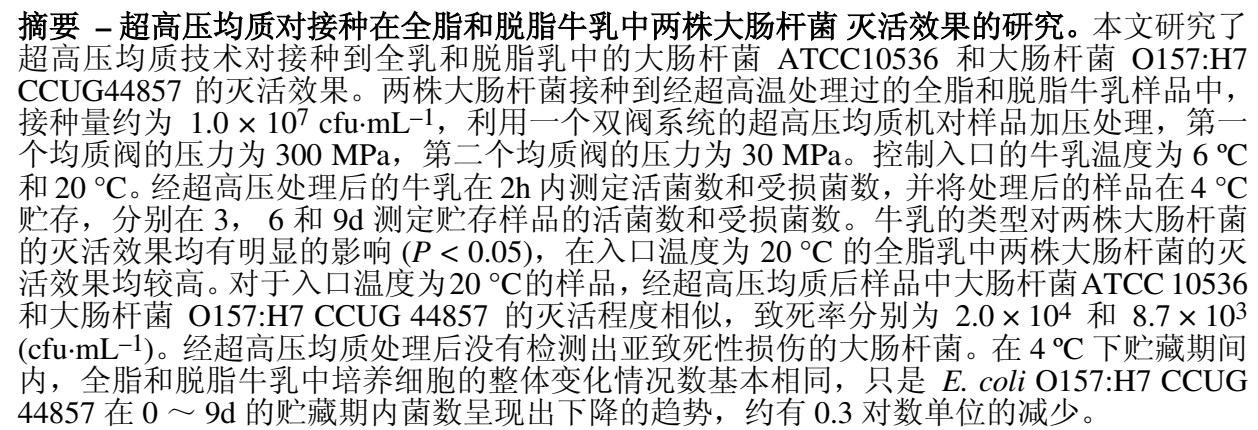

超高压均质 / 致死率 / 牛乳 / 大肠杆菌 O157:H7 / 亚致死性损伤

* Corresponding author (通讯作者): arturxavier.roig@uab.es 
Résumé - Inactivation par homogénéisation à très haute pression de deux souches d'Escherichia coli inoculées au lait entier ou écrémé. L'inactivation par homogénéisation à très haute pression (UHPH) d'Escherichia coli ATCC 10536 et d'Escherichia coli O157:H7 CCUG 44857 inoculées au lait entier et au lait écrémé a été étudiée. Des échantillons de lait entier ou écrémé UHT ont été inoculés avec des souches à une concentration approximative de $7,0 \log _{10}\left(\mathrm{cfu} \cdot \mathrm{mL}^{-1}\right)$ et ont ensuite été mis sous pression dans une machine de UHPH composée de deux pistons, le premier avec un système de soupape homogénéisant à $300 \mathrm{MPa}$, le second avec une soupape à $30 \mathrm{MPa}$. Les températures initiales du lait étaient de $6{ }^{\circ} \mathrm{C}$ et $20^{\circ} \mathrm{C}$. Le comptage des microorganismes vivants et ceux ayant subi des dommages a été fait 2 heures après le traitement UHPH et au $3^{\mathrm{e}}, 6^{\mathrm{e}}$, et $9^{\mathrm{e}}$ jours de conservation à $4^{\circ} \mathrm{C}$. La nature du lait a influencé significativement $(P<0,05)$ le degré d'inactivation atteint pour les deux souches d' E. coli, et de manière plus importante dans le lait entier pour une température de $20{ }^{\circ} \mathrm{C}$. Le niveau d'inactivation était similaire pour E. coli ATCC 10536 et E. coli O157:H7 CCUG 44857, atteignant respectivement les valeurs létales de 4,30 et $3,94 \log _{10} \mathrm{cfu} \cdot \mathrm{mL}^{-1}$ à une température initiale de $20^{\circ} \mathrm{C}$. Aucun dommage subletal n'a été détecté sur les souches après les traitements. L'évolution des microorganismes vivants durant la conservation à $4{ }^{\circ} \mathrm{C}$ était similaire dans le lait entier et le lait écrémé. La souche E. coli O157:H7 CCUG 44857 a montré une tendance à la baisse de 0,3 unités logarithmiques et des différences significatives entre le 1 er jour et le $9 \mathrm{e}$ jour de conservation.

homogénéisation à très haute pression / inactivation / lait / Escherichia coli 0157:H7 / blessure sublétale

\section{INTRODUCTION}

The nutritional attributes of milk which make it an important part of the human diet are the same components that support the growth of many pathogenic bacteria associated with milk and dairy products [25]. A broad spectrum of microbial pathogens can contaminate human food and cause illnesses when they or their toxins are consumed [21]. Contaminated milk and dairy products have been associated with foodborne outbreaks caused by Salmonella spp., Listeria monocytogenes, Yersinia enterocolitica, Staphylococcus aureus and Escherichia coli $\mathrm{O} 157: \mathrm{H} 7$ [1, 11, 19, 25]. Consumption of raw milk contaminated with Escherichia coli $\mathrm{O} 157: \mathrm{H} 7$ is probably the most likely source of infection in diverse outbreaks which have occurred during the last decade $[15,18,19]$.

Heat treatment is the most commonly chosen preservation method for milk and other perishable liquid foods. Thermal processing has a long tradition in food preservation because it is economical and efficient at achieving microbial inactivation, but it cannot be used to treat heat-labile compounds. Furthermore, high temperatures may lead to undesirable effects in milk such as off-flavours, nonenzymatic browning and denaturation of certain vitamins and proteins $[5,7,23]$.
The growing trend for fresher, highquality convenience food has generated an increasing interest in nonthermal processing alternatives, such as high-pressure technologies, which are considered to be the most promising emerging food-processing technologies due to recent advances in high-pressure machinery and the successful introduction of pressure-processed foods $[5,7,8,12,14]$. Ultrahigh-pressure homogenisation UHPH (also called dynamic high pressure in the literature) is based on the same design principles as conventional homogenisation processes that are used in the dairy industry for reducing the size of fat globules [10, 22, 23], but working at significantly higher pressures $(>200 \mathrm{MPa})$, resulting in the destruction of large quantities of microorganisms. Consequently, this technology appears to be an important means of lowering the initial microbial load while helping to minimise product damage from unnecessary heat stress [17]. The effects of UHPH on bacterial cells are not yet well known, but some studies on UHPH have shown changes in bacterial cell morphology, as well as splits in the cytoplasmic membrane. Sudden increases in permeability or rupture of the cell membrane, such as may occur under pressure, cause cell death [9, 12, 13, 23]. Vannini et al. [24] and Vachon et al. [23] reported that UHPH treatments induced cell damage whose 
severity increased with pressure level and number of cycles to which the sample was submitted. The damage observed was more severe on bacterial cells, including discharges of cytoplasmic content when pressure increased. Information concerning the effect of the matrix on the degree of inactivation showed by the microorganisms is scarce. The available results seem to indicate that UHPH treatments were more effective against microorganisms in saline buffered solutions than in more complex matrices such as milk [7, 23].

The main objective of this work was to study the inactivation of two different strains of Escherichia coli: E. coli O59:H21 (ATCC 10536) and E. coli O157:H7 (CCUG 44857), inoculated into whole and skim milk using a new-generation UHPH machine with two intensifiers and a doublevalve system. We also studied the effect of inlet temperature of the milk, type of food matrix and the strain kind on the inactivation rate, the capacity of UHPH treatments to produce sublethal injuries, and the ability of the microorganisms to repair and grow during further refrigerated storage.

\section{MATERIALS AND METHODS}

\subsection{Bacterial strains used and growing conditions}

Escherichia coli O59:H21 ATCC 10536 and Escherichia coli O157:H7 CCUG 44857 were obtained as freeze-dried cultures in thermosealed vials from the Spanish Type Culture Collection (University of Valencia, Valencia, Spain). The freezedried cultures were rehydrated in tryptone soy broth (Oxoid Ltd., Basingstoke, Hampshire, England) at $37^{\circ} \mathrm{C}$ for $18 \mathrm{~h}$. Subsequently, these broths were used to inoculate tryptone soy agar plate (Oxoid), and individual colonies were collected to prepare cryobeads (Nalgene ${ }^{\circledR}$ System $100^{\mathrm{TM}}$ Laboratories Microkit Iberica S.L., Madrid, Spain) of each strain. They were then kept at $-20{ }^{\circ} \mathrm{C}$ to provide stock cultures for the assays.

\subsection{Preparation of cell suspension and inoculation of whole and skim milk}

Prior to each experiment one cryobead was inoculated into $10 \mathrm{~mL}$ of tryptone soy broth (Oxoid) and incubated at $37{ }^{\circ} \mathrm{C}$ for $20 \mathrm{~h}$. After incubation, the broth was spread using a disposable loop on tryptone soy agar slant (Oxoid) incubated at $37^{\circ} \mathrm{C}$ for $20-24 \mathrm{~h}$. Subsequently, cell suspensions were prepared in $11 \mathrm{~mL}$ tryptone sodium chloride solution (TSC) $\left(1 \mathrm{~g} \cdot \mathrm{L}^{-1}\right.$ tryptone pancreatic casein digestion and $8.5 \mathrm{~g} \cdot \mathrm{L}^{-1}$ sodium chloride) in order to obtain $9.0 \log _{10} \mathrm{cfu} \cdot \mathrm{mL}^{-1}$ to $9.5 \log _{10} \mathrm{cfu} \cdot \mathrm{mL}^{-1}$. Thereafter, $1 \mathrm{~mL}$ of cell suspension was used to determine the concentration by means of optical density at $405 \mathrm{~nm}\left(405 \mathrm{OD}_{405}\right)$ using a spectrophotometer (Cecil 9000 series, Cecil instruments, Cambridge, England). Later, $10 \mathrm{~mL}$ of this cell suspension was inoculated into one L of UHT whole and skim milk at room temperature. The final concentration of cells in milk was $7.0 \log _{10} \mathrm{cfu} \cdot \mathrm{mL}^{-1}$ to 7.5 $\log _{10} \mathrm{cfu} \cdot \mathrm{mL}^{-1}$. The inoculated milk samples were placed for $70 \mathrm{~min}$ at 6 and $20^{\circ} \mathrm{C}$ in a water bath to reach pressurisation temperature.

\subsection{Ultrahigh-pressure homogenisa- tion treatment of the milk}

UHPH treatments were applied to the milk samples using a Stansted high-pressure homogeniser (model/DRG FPG7400H:350, Stansted Fluid Power Ltd, Essex, UK). This high-pressure machine comprises two intensifiers ( $80 \mathrm{~mL}$ useful volume), driven by a hydraulic pump and a high-pressure valve made of resistant ceramics able to support $350 \mathrm{MPa}$. It also comprises a second pneumatic valve able to support $50 \mathrm{MPa}$ located behind the first one. All these components guarantee a constant flow rate $\left(18 \mathrm{~L} \cdot \mathrm{h}^{-1}\right)$ during the process. To avoid poor homogenisation performance due to temperature increase and rapid expansions or contractions in the first stage valve, the latter is cooled by constant circulation of water at room temperature in an external jacket built around the valve. Milk was subjected to a single cycle at UHPH of 
$300 \mathrm{MPa}$ at the primary homogenising valve and $30 \mathrm{MPa}$ at the secondary valve $(300+30 \mathrm{MPa})$ at inlet temperatures of 6 and $20^{\circ} \mathrm{C}$. For the experiment $2.0 \mathrm{~L}$ of each type of inoculated milk were used, with the majority of this volume being processed through the homogeniser to ensure temperature equilibration. Afterwards, between 80 and $100 \mathrm{~mL}$ of the samples were taken for analysis. The homogenised samples reached an outlet temperature of 16.0 to $18.0^{\circ} \mathrm{C}$ by means of: (i) an external jacket built around the pipeline located between the first and second homogenising valves and (ii) a spiral-type heat-exchanger (BCI/2843 type, Occo Cooller Ltd, Telford, UK) located behind the second valve. The samples were immediately stored at $4{ }^{\circ} \mathrm{C}$.

A specific sanitation programme developed for the UHPH machine was applied each time immediately after submitting the milk samples to UHPH treatment. A mixture of peracetic acid and hydrogen peroxide (P3-Oxonia Active, Ecolab Hispanic Portuguese, Barcelona, Spain) was used as a disinfectant agent, whose bactericidal efficacy was previously evaluated using a quantitative test of suspension [2]. We also carried out several experiments to adjust the conditions of cleaning and disinfection in the UHPH machine. The sanitation sequence of the machine was applied according to methodology developed by Briñez et al. [3].

\subsection{Microbiological analysis}

To determine the initial number of cells in the inoculated samples of milk at 6 and $20^{\circ} \mathrm{C}, 1 \mathrm{~mL}$ of each sample was used to prepare decimal dilutions in peptone water (Oxoid, $10 \mathrm{~g} \cdot \mathrm{L}^{-1}$ peptone and $5 \mathrm{~g} \cdot \mathrm{L}^{-1}$ $\mathrm{NaCl}$ ). Subsequently, $1 \mathrm{~mL}$ of these dilutions was placed in duplicate in tryptone soy agar plate (Oxoid) supplemented with $6 \mathrm{~g} \cdot \mathrm{L}^{-1}$ yeast extract (Oxoid, TSAYE) and incubated at $37^{\circ} \mathrm{C}$ for $48 \mathrm{~h}$. Also, $20 \mathrm{~mL}$ of the untreated inoculated samples (controls) were placed into sterile tubes and stored at $4{ }^{\circ} \mathrm{C}$.

The first microbiological analysis of treated and control samples was performed $2 \mathrm{~h}$ after the UHPH treatment. Afterwards samples were kept at $4{ }^{\circ} \mathrm{C}$ and analysed after 3,6 and 9 days of storage. To assess the lethality and the level of injuries caused by UHPH treatment, decimal dilutions in peptone water (Oxoid) of untreated and treated milk samples were prepared and plated in duplicate in TSAYE, and TSAYE supplemented with $20 \mathrm{~g} \cdot \mathrm{L}^{-1}$ of $\mathrm{NaCl}$ (Panreac, Moncada i Reixac, Barcelona, Spain; TSAYE $+\mathrm{NaCl}$ ) and incubated at $37^{\circ} \mathrm{C}$ for $48 \mathrm{~h}$. The use of this differential plating technique enables injuries to be monitored. Both noninjured and injured cells were able to form colonies on TSAYE, whereas only noninjured cells formed colonies in the presence of $\mathrm{NaCl}$ [16]. Results were expressed as the logarithm of cfu. $\mathrm{mL}^{-1}$. Lethality was calculated as the difference between the logarithms of colony counts of the untreated and treated samples $\left(\log _{10} \mathrm{~N}_{0}-\log _{10} \mathrm{~N}\right)$.

\subsection{Statistical treatment of data}

All experiments were repeated four times with duplicate analysis in each replicate. Data are presented as least square means of each experiment. Analysis of variance was performed using the General Lineal Models Procedure (GLM) of SAS ${ }^{\circledR}$ System [20]. Evaluation was based at a level of significance of $P<0.05$.

\section{RESULTS AND DISCUSSION}

UHPH treatments applied at $300+30 \mathrm{MPa}$ in a single cycle at inlet temperatures of $6{ }^{\circ} \mathrm{C}$ and $20^{\circ} \mathrm{C}$ were able to reduce significantly the counts of E. coli ATCC 10536 and E. coli $\mathrm{O} 157: \mathrm{H} 7 \mathrm{CCUG} 44857$. No statistical differences between strains were found when the treatment was applied in the same matrix and at the same inlet temperature (Fig. 1). Either the inlet temperature of the sample or the type of food matrix significantly influenced $(P<0.05)$ the degree of inactivation reached. The highest lethality values were observed for the strain E. coli ATCC 10536 inoculated into whole milk at an inlet temperature of $20{ }^{\circ} \mathrm{C}$ (4.30 $\left.\log _{10} \mathrm{cfu} \cdot \mathrm{mL}^{-1}\right)$. The inoculated samples of skim milk treated at $6^{\circ} \mathrm{C}$ showed 

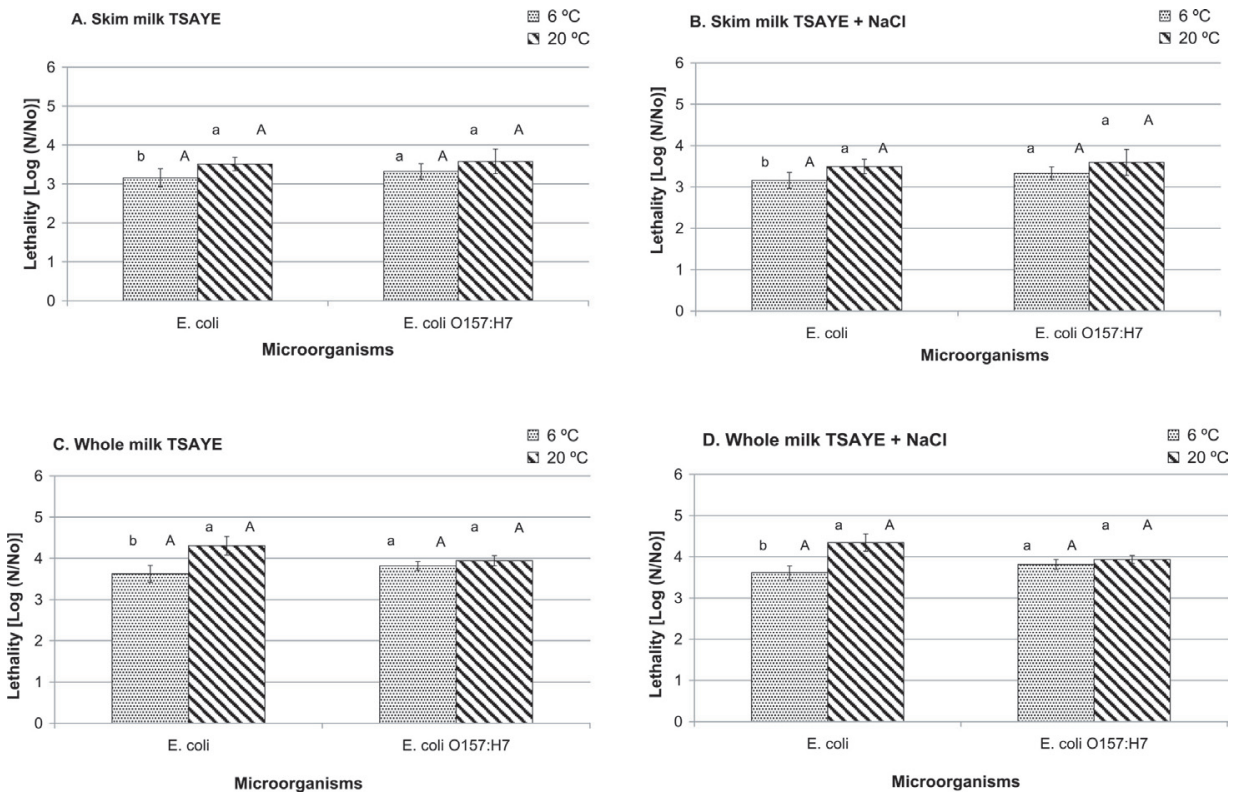

Figure 1. Inactivation of Escherichia coli (ATCC 10536) and Escherichia coli O157:H7 (CCUG 44857), in skim (A, B) and whole milk (C, D) treated with ultrahigh-pressure homogenisation (300 $+30 \mathrm{MPa}$ ) using inlet temperatures of 6 and $20^{\circ} \mathrm{C}$. Survivors were enumerated using tryptone soy agar with yeast extract (TSAYE) and TSAYE with $20 \mathrm{~g}$ of salt added per litre (TSAYE $+\mathrm{NaCl}$ ) with incubation at $37^{\circ} \mathrm{C}$ for $48 \mathrm{~h}$. Bars with different superscript small letters are significantly different $(P \leq 0.05)$ for the same microorganism. Bars with different superscript capital letters are significantly different $(P \leq 0.05)$ for the same inlet temperature. Data are presented as the mean values of four replications \pm confidence intervals.

the lowest values of lethality for $E$. coli ATCC 10536 and E. coli O157:H7 CCUG 44857 (3.15 and $3.32 \log _{10} \mathrm{cfu} \cdot \mathrm{mL}^{-1}$, respectively).

Diels et al. [7] also reported reductions of around 3.5 $\log _{10}$ cycles in E. coli (strain MG1655) when inoculated into skim milk pressurised at $300 \mathrm{MPa}$ in one single cycle, but using a higher inlet temperature $\left(25^{\circ} \mathrm{C}\right)$. Inlet temperature may influence the maximum temperature reached during the process, and consequently, may affect the lethality reached. In our work the lethality increased by $0.13-0.70 \quad \log _{10}$ cycles depending on the matrix type when the inlet temperature increased from $6{ }^{\circ} \mathrm{C}$ to $20^{\circ} \mathrm{C}$. However, these lethalities are still far away from the ones described by Vachon et al. [23] who reported reductions of approximately $8 \log _{10}$ cycles in cultivable cells in another strain of E. coli (E. coli O157:H7 ATCC 35150) when inoculated into whole raw milk pressurised at $300 \mathrm{MPa}$ with an inlet temperature of $25^{\circ} \mathrm{C}$, using the same model of UHPH machine employed by Diels et al. [7] (Emusiflex C5, Avestin, Ottowa, Canada). They also reported that increasing the milk temperature from $55^{\circ} \mathrm{C}$ to $60^{\circ} \mathrm{C}$ brought an additional reduction of 1.2 logarithmic units in cultivable cells of E. coli $\mathrm{O} 157: \mathrm{H} 7$. This seems to indicate that the type of strain used (E. coli MG1655 or E. coli O157:H7 ATCC 35150) and pressurisation conditions (control of the rise in temperature during and after the pressurisation) may influence the results, although in our study, we did not detect significant differences between the two strains of $E$. coli. An inlet temperature of $6^{\circ} \mathrm{C}$ would be interesting for the milk industry since milk could 
be treated just after being unloaded from the containers without breaking out of the refrigeration conditions. However, $3 \log _{10}$ units of reduction could be not sufficient, depending on the microbiological quality of the raw milk.

The other factor that greatly influences the efficacy of the treatments is the kind of matrix. If we compare the reductions shown by Vachon et al. [23] with the ones reported by Diels et al. [7] at the same pressure and inlet temperature $\left(300 \mathrm{MPa}, 25^{\circ} \mathrm{C}\right)$, a clear difference between skim milk and whole milk is observed in favour of whole milk; results that agree with ours, although they used slightly higher temperatures $\left(25^{\circ} \mathrm{C}\right)$. Moreover, Vachon et al. [23] also observed lower lethality values for $E$. coli $\mathrm{O} 157: \mathrm{H} 7$ when treated $\left(300 \mathrm{MPa}\right.$ at $25^{\circ} \mathrm{C}$ of inlet temperature and one pass) in phosphate-buffered saline (6 $\log _{10} \mathrm{cfu} \cdot \mathrm{mL}^{-1}$ approximately) than when it was inoculated into raw milk $\left(8.5 \log _{10} \mathrm{cfu} \cdot \mathrm{mL}^{-1}\right)$. Similar results were previously reported by Gervilla et al. (2000) [8] in milk with different percentages of fat $(0,6$ and $50 \%)$, but treated with high hydrostatic pressure (400 MPa, 15 minutes). It seems that fat increases the piezosensibility of the microorganisms, in contrast with heat treatments where fat is assumed to have a protective effect. These researchers suggested that the cause might be the increase in the concentration of certain liposoluble substances with an antimicrobial effect caused by the increase in the fat content, which causes interchanging of triglycerides of milk with lipoproteins of the cellular membrane, altering the permeability of microorganisms. However, more recently Diels et al. [6, 7] identified fluid viscosity as a major environmental parameter affecting bacterial inactivation by UHPH.

No significant differences were observed in the lethality values of either strain between TSAYE and TASAYE $+\mathrm{NaCl}$ media within the same food matrix and inlet temperature, indicating that the UHPH treatment caused no sublethal injuries. This was previously observed for other microorganisms such as Yersinia enterocolitica, Staphylococcus aureus and Salmonella enterica serovar typhimurium [26, 27]. Wuytack et al. [27] compared five different treatments, reporting that high levels of sublethal injuries were observed for high hydrostatic pressure and heat treatments compared with treatment with pulsed white light, pulsed electric field and UHPH, which showed very low levels or even no sublethal injury. In a previous investigation by our group [3] we observed that UHPH treatment caused few or no sublethal injuries in Listeria innocua inoculated into whole milk and orange juice. This is the point that clearly makes the effect of this technology different from high hydrostatic pressure, which can cause accumulation of sublethal injuries, leading to subsequent recovery of the cells, depending on the conditions of treatment and later storage [4].

The evolution of cultivable cells of E. coli $\mathrm{O} 157: \mathrm{H} 7$ (CCUG 4485) during the later storage at $4^{\circ} \mathrm{C}$ was similar in all samples, showing a slight but significant $(P<0.05)$ decrease of approximately 0.3 logarithmic units between days 0 and 9 of storage (Fig. 2). However, in the case of the strain ATCC 10536 their counts did not significantly differ during the whole storage (Fig. 3).

The low temperature of storage did not exert any significant effect on the behaviour of cultivable cells of $E$. coli $\mathrm{O} 157: \mathrm{H} 7$ in the treated samples, showing a similar evolution to the control samples (Fig. 2). No other references were found to the evolution of $E$. coli treated by UHPH and stored at low temperatures. Vannini et al. [24] reported an increment in the cultivable cells of $E$. coli of approximately 3.5 logarithmical units in skim milk after being treated at $130 \mathrm{MPa}$, but after 33 hours of incubation at $37^{\circ} \mathrm{C}$. In our work, the changes in cultivable cells remained steady or, in the case of the E. coli O157:H7 CCUG 44857 strain, showed a slightly decreasing tendency after 9 days of storage at $4{ }^{\circ} \mathrm{C}$ although the physical-chemical characteristics of milk ( $\mathrm{pH}$ of 6.7 close to neutrality and a large presence of nutrients) are very favourable to this microorganism. De Lamo-Castellví et al. [4] reported that various strains of Yersinia enterocolitica were able to increase their counts in skim milk by about $8 \log _{10}$ cycles after 15 days of storage at $8{ }^{\circ} \mathrm{C}$ after being submitted to a high hydrostatic-pressure treatment of $500 \mathrm{MPa}$ that apparently 

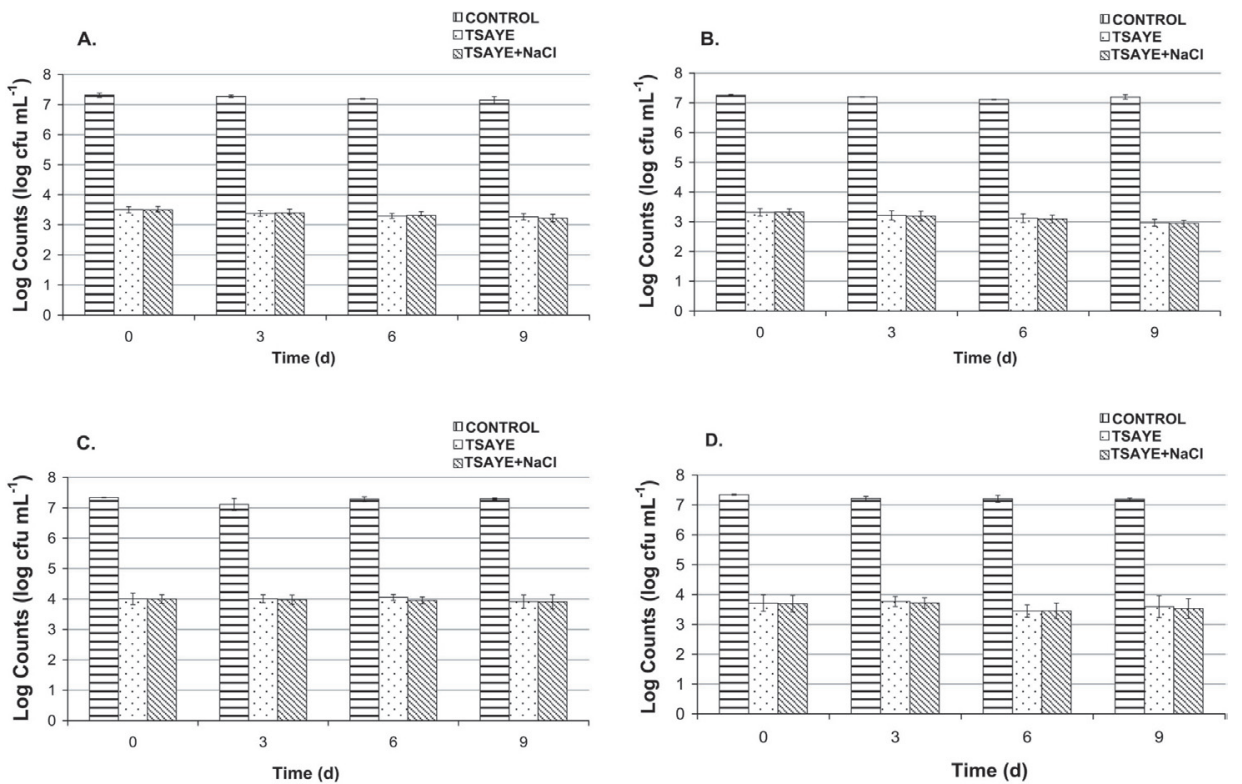

Figure 2. Changes in cultivable cells of Escherichia coli O157:H7 (CCUG 44857), in whole and skim milk pressurised at $300+30 \mathrm{MPa}$ and stored at $4{ }^{\circ} \mathrm{C}$. (A) Whole milk pressurised at inlet temperature of $6{ }^{\circ} \mathrm{C}$. (B) Whole milk pressurised at inlet temperature of $20^{\circ} \mathrm{C}$. (C) Skim milk pressurised at inlet temperature of $6^{\circ} \mathrm{C}$. (D) Skim milk pressurised at inlet temperature of $20^{\circ} \mathrm{C}$. The data are presented as the mean value of four replications $\pm 95 \%$ confidence interval.

caused its complete inactivation. E. coli is not a psychrotrophic bacterium and an increase in its count in milk at $4{ }^{\circ} \mathrm{C}$ is not expected, but we could have expected a greater sensitivity of surviving cells to unfavourable growing conditions, such as low temperature. We also observed in studies with another strains that Staphylococcus aureus significantly decreased their counts during cheese ripening after submitting the inoculated milk to a similar UHPH treatment prior to cheese elaboration; meanwhile, in cheeses elaborated from untreated milk their counts remained steady during the ripening period (data not shown). This indicated that although surviving cells can grow in culture media, they showed a greater sensibility to unfavourable environment conditions (low $\mathrm{pH}$ and salt) than cells from the untreated samples. If the cells that survive UHPH treatment are not injured, as was previously discussed, it can be supposed that they will not be more sensitive to unfavourable growing conditions, such as low temperature. In our trials, no significant differences were observed in cultivable cells between TSAYE and TASAYE + $\mathrm{NaCl}$ at any day of storage for samples at the same conditions and no differences were detected in the evolution of either strain between the treated ones and the controls (Figs. 2 and 3), confirming that UHPH treatments did not increase the sensitivity of the cell to low temperatures of storage.

\section{CONCLUSION}

The results indicate than even low inlet temperatures $\left(6\right.$ and $20{ }^{\circ} \mathrm{C}$ ) affect the lethality values in UHPH treatments only for the Escherichia coli ATCC 10536 strain. These temperatures were efficient at reducing the cultivable cells in whole and skim milk treated at $300+30 \mathrm{MPa}$, which is interesting since pre-heating milk implies an increase in the treatment costs. Pre-heating 

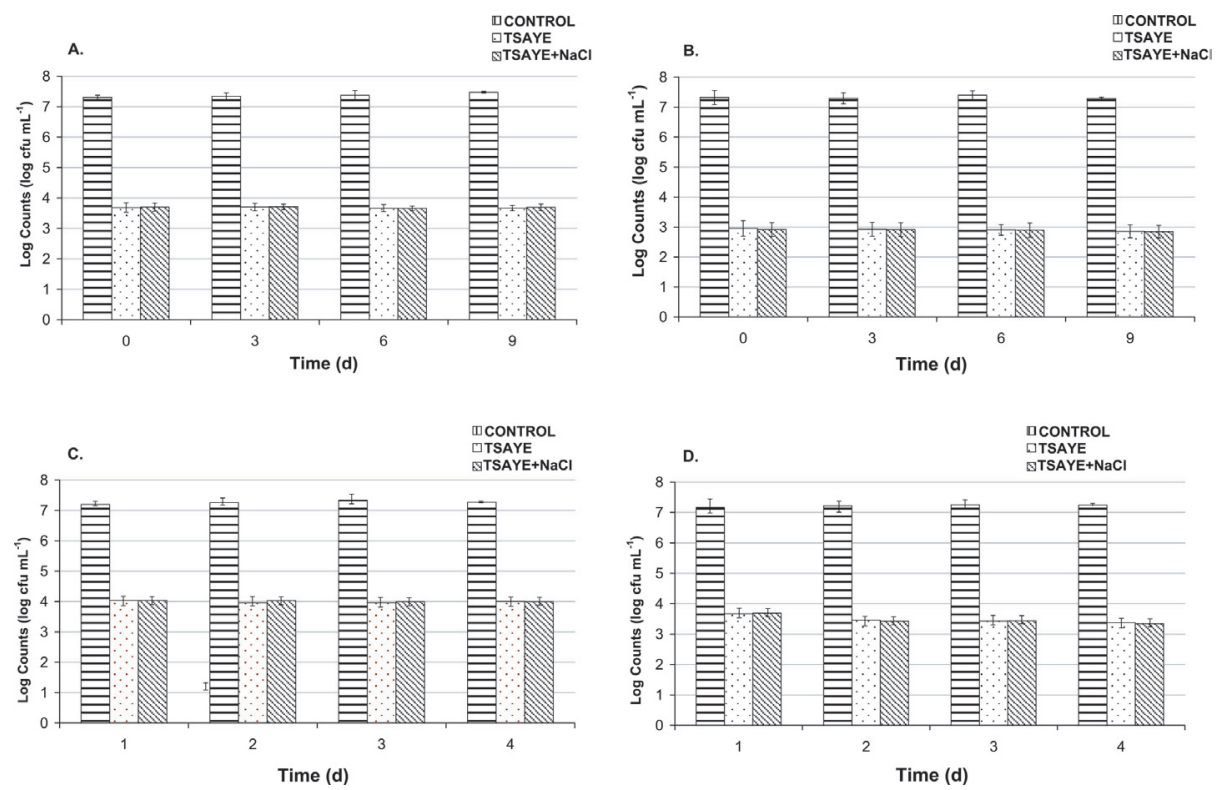

Figure 3. Changes in cultivable cells of Escherichia coli (ATCC 10536), in whole and skim milk pressurised at $300+30 \mathrm{MPa}$ and stored at $4^{\circ} \mathrm{C}$. (A) Whole milk pressurised at inlet temperature of $6{ }^{\circ} \mathrm{C}$. (B) Whole milk pressurised at inlet temperature of $20^{\circ} \mathrm{C}$. (C) Skim milk pressurised at inlet temperature of $6{ }^{\circ} \mathrm{C}$. (D) Skim milk pressurised at inlet temperature of $20^{\circ} \mathrm{C}$. The data are presented as the mean value of four replications $\pm 95 \%$ confidence interval.

milk to higher temperatures would probably increase the lethality values after UHPH treatment. Fat content did not increase the resistance of the microorganism to UHPH; on the contrary, the presence of fat significantly increased the efficacy of the treatment and the further survival capability during the subsequent storage period of E. coli. The role of fat in the baro-resistance of microorganisms in comparison with heat treatments needs further research. Considering that UHPH treatment did not cause sublethal injuries, this technology may offer a promising alternative to the pasteurisation of milk and others liquid foods, supported by the possibility of increasing the inlet temperature of the sample before the process.

Acknowledgements: The authors acknowledge the financial support received from the Centre Especial de Recerca Planta de Tecnología Dels Aliments (CERPTA) by means of the CRAFT project $512626 \mathrm{UHPH}$, which per- mitted us to accomplish this research, and the grant given to Wilfido José Briñez Zambrano by the Fondo Nacional de Ciencia, Tecnología e Inovación (FONACIT) and Universidad del Zulia of Venezuela for Ph.D. studies.

\section{REFERENCES}

[1] Altekruse S.F., Timbo B.B., Mowbray J.C., Bean N.H., Potter M.E., Cheese-associated outbreaks of human illness in the United States, 1973 to 1992: sanitary manufacture practices protect consumer, J. Food Prot. 61 (1998) 1405-1407.

[2] Briñez W.J., Roig-Sagués A.X., HernándezHerrero M.M., López-Pedemonte T., Guamis B., Bactericidal efficacy of peracetic acid in combination with hydrogen peroxide against pathogenic and non pathogenic strains of Staphylococcus spp., Listeria spp. and Escherichia coli, Food Control 17 (2006) 516-521.

[3] Briñez W.J., Roig-Sagués A.X., HernándezHerrero M.M., Guamis-López B., Inactivation of Listeria innocua in milk and orange juice using ultrahigh-pressure homogenisation, J. Food Prot. 69 (2006) 86-92. 
[4] De Lamo-Castellví S., Capellas M., LópezPedemonte T., Hernández-Herrero M.M., Guamis B., Roig-Sagués A.X., Behaviour of Yersinia enterocolitica strains inoculated in model cheese treated with high hydrostatic pressure, J. Food Prot. 68 (2005) 528-523.

[5] Diels A.M.J., Wuytack E.Y., Michiels C.W., Modelling inactivation of Staphylococcus aureus and Yersinia enterocolitica by highpressure homogenisation at different temperatures, Int. J. Food Microbiol. 87 (2003) 55-62.

[6] Diels A.M.J., Callewaert L., Wuytack E.Y., Masschalck B., Michiels C.W., Moderate temperatures affect Escherichia coli inactivation by high-pressure homogenisation only through fluid viscosity, Biotechnol. Prog. 20 (2004) 1512-1517.

[7] Diels A.M.J., Callewaert L., Wuytack E.Y., Masschalck B., Michiels C.W., Inactivation of Escherichia coli by high-pressure homogenisation is influenced by fluid viscosity but not by water activity and product composition, Int. J. Food Microbiol. 101 (2005) 281-291.

[8] Gervilla R., Ferragut V., Guamis B., High pressure inactivation of microorganisms inoculated into ovine milk of different fat contents, J. Dairy Sci. 83 (2000) 674-682.

[9] Guerzoni M.E., Vannini L., Chaves López C., Lanciotti R., Suzzi G., Gianotti A., Effect of high pressure homogenization on microbial and chemico-physical characteristics of goat cheeses, J. Dairy Sci. 82 (1999) 851-862.

[10] Hayes M.G., Kelly A.L., High pressure homogenisation of raw whole bovine milk (a) effects on fat globule size and other properties, J. Dairy Res. 70 (2003) 297-305

[11] Johnson J.L., Rose B.E., Sharar A.K., Ramsom G.M., Lattuada C.P., McNamara A.M., Methods used for detection and recovery of Escherichia coli $\mathrm{O} 157: \mathrm{H} 7$ associated with food-borne disease outbreak, J. Food Prot. 58 (1995) 597-603.

[12] Kheadr E.E., Vachon J.F., Paquin P., Fliss I., Effect of dynamic high pressure on microbiological, rheological and microstructural quality of Cheddar cheese, Int. Dairy J. 12 (2002) 435-446.

[13] Lanciotti R., Gardini F., Sinigaglia M., Guerzoni M.E., Effects of growth conditions on the resistance of some pathogenic and spoilage species to high pressure homogenization, Lett. Appl. Microbiol. 22 (1996) 165-168.

[14] Lucore L.A., Shellhammer T.H., Yousef A.E., Inactivation of Listeria monocytogenes Scott A on artificially contaminated frankfurters by high-pressure processing, J. Food Prot. 63 (2000) 662-664.
[15] Orden J.A., Cid D., Ruiz-Santa-Quiteria J.A., García S., Martínez S., De la Fuente R., Verotoxin-producing Escherichia coli (VTEC) enteropatogenic E. coli (EPEC) and necrotoxigenic $E$. coli (NTEC) isolated from healthy cattle in Spain, J. Appl. Microbiol. 93 (2002) 29-35.

[16] Patterson M.F., Quinn M., Simpson R., Gilmour A., Sensitivity of vegetative pathogens to high hydrostatic pressure treatment in phosphate-buffered saline and foods, J. Food Prot. 58 (1995) 524-529.

[17] Popper L., Knorr D., Applications of highpressure homogenization for food preservation, Food Technol. 44 (1990) 84-89.

[18] Simmons N.A., Global perspective on Escherichia coli $\mathrm{O} 157: \mathrm{H} 7$ and other verocytotoxic E. coli spp.: UK views, J. Food Prot. 60 (1997) 1463-1465.

[19] Sparling P.H., Escherichia coli O157:H7 outbreaks in the United States, 1982-1996, JAVMA 213 (1998) 1733.

[20] Statiscal Analysis Systems Institute, User's Guide. Version 8, SAS Institute Inc., Cary, NC, USA, 1999.

[21] Tauxe R.V., Emerging foodborne pathogens, Int. J. Food Microbiol. 78 (2002) 31-41.

[22] Thiebaud M., Dumay E., Picart L., Guiraud J.P., Cheftel J.C., High-pressure of raw bovine milk. Effects on fat globule size distribution and microbial inactivation, Int. Dairy J. 13 (2003) 427-439.

[23] Vachon J.F., Kheadr E.E., Giasson J., Paquin P., Fliss I., Inactivation of foodborne in milk using dynamic high pressure, J. Food Prot. 65 (2002) 345-352.

[24] Vannini L., Lanciotti R., Baldi D., Guerzoni M.E., Interactions between high pressure homogenization and antimicrobial activity of lysozyme and lactoperoxidasa, Int. J. Food Microbiol. 94 (2004) 123-136.

[25] Wang G., Zhao T., Doyle M.P., Survival and growth of Escherichia coli $\mathrm{O} 157: \mathrm{H} 7$ in unpasteurized and pasteurized milk, J. Food Prot. 60 (1997) 610-613.

[26] Wuytack E.Y., Diels A.M.J., Michiels C.W., Bacterial inactivation by high-pressure homogenisation and high hydrostatic pressure, Int. J. Food Microbiol. 77 (2002) 205-212.

[27] Wuytack E.Y., Phuong L.D.T., Aertsen A., Reyns K.M.F., Marquenie D., De Ketelaere B., Masschalck B., Van Opstal I., Diels A.M.J., Michiels C.W., Comparison of sublethal injury induced in Salmonella enterica serovar typhimurium by heat and by different nonthermal treatments, J. Food Prot. 66 (2003) 31-37. 